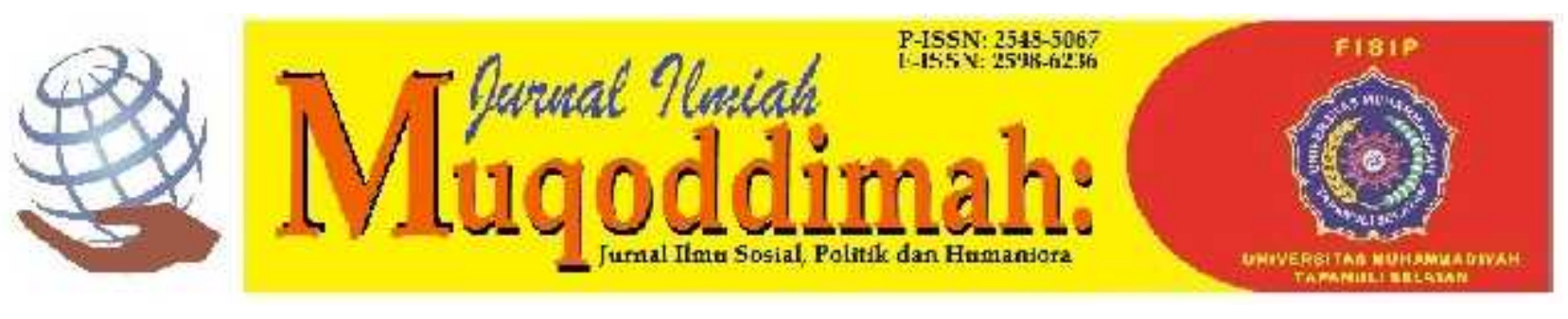

\title{
Faktor-Faktor Yang Mempengaruhi Voter Turnout Pada Kalangan Perempuan
}

\author{
Ihsan Ma'zhumi ${ }^{1}$, Yusa Djuyandi ${ }^{2)}$, Mudiyati Rahmatunnisa ${ }^{3)}$ \\ Fakultas IImu Sosial dan IImu Politik, Universitas Padjajaran \\ Jl. Raya Bandung Sumedang KM 21, Hegarmanah, Kec. Jatinangor, Kabupaten Sumedang, Jawa Barat \\ altratimuri@gmail.com ${ }^{1)}$ \\ fyusa@yahoo.com ${ }^{2}$ \\ ;m.rahmatunnisa@unpad.ac.id ${ }^{3)}$
}

\begin{abstract}
Abstrak
Jumlah partisipasi perempuan dalam politik cukup menggembirakan. Data tentang pemilih selama sepuluh tahun terakhir menunjukkan peningkatan jumlah partisipasi perempuan dalam pemilihan selama pemilihan. Kegiatan memilih dalam ilmu politik umumnya dikenal sebagai partisipasi pemilih. Penelitian ini bertujuan untuk menyelidiki faktor-faktor apa yang mempengaruhi jumlah pemilih. Untuk mendapatkan data, kami menggunakan kuesioner dikotomi untuk mendapatkan informasi tentang alasan apa yang ada di setiap responden yang membuat mereka memilih. Dengan menggunakan prosedur statistik nonparametrik, kami mengumpulkan hampir 400 responden. Hasil penelitian kami menunjukkan bahwa usia, minat terhadap politik, hak warga negara, ukuran populasi, stabilitas populasi, kondisi perkembangan ekonomi, fragmentasi politik, sistem pemilihan, waktu pelaksanaan pemilihan, persyaratan pendaftaran pemilih dan pengaturan suara mempengaruhi jumlah perempuan. Hasil ini menyiratkan bahwa hal-hal yang menjadi alasan seseorang memberikan suaranya adalah sekumpulan konsep yang rumit. Jika penyelenggara pemilu dan peserta pemilu membutuhkan peningkatan jumlah pemilih di kalangan perempuan, mereka harus mempertimbangkan untuk melihat faktor internal dan eksternal secara holistik.
\end{abstract}

Kata kunci :perempuan, politik, voter turnout

\begin{abstract}
The number of women's participation in politics is encouraging. The data about voters over the past ten years show increasing numbers of women's participation in voting during elections. Voting activities in political science are commonly known as voter turnout. This study aims to investigate what factors influence voter turnout. To obtain the data, we use a dichotomy questionnaire to get information about what reason that lies in every respondent that make them vote. Using the nonparametric statistical procedures, we gathering nearly 400 respondent. The results found that age, political interest, citizens' rights, population size, population stability, economic development conditions, political fragmentation, electoral system, electoral implementation time, voter registration requirements and voting arrangements influence women's turnout. This result implies that the things that are the reason someone gives their votes are complicated. If the election organizers and election participants need an increase in voter turnout among women, they must consider viewing the internal and external factor holistically.
\end{abstract}

Key word :politics, women, voter turnout 


\section{PENDAHULUAN}

Memilih adalah bagian dari hak asasi manusia. Setiap orang yang telah memenuhi kriteria sebagai pemilih berhak menentukan pilihannya. Pemilihan Umum (Pemilu) sebagai manifestasi demokrasi Pemilihan umum adalah proses politik yang melibatkan semua warga negara, baik pria maupun perempuan (Budiardjo, 2004). Sensus nasional oleh Badan Pusat Statistik (BPS) Republik Indonesia menunjukkan bahwa mayoritas dari masyarakat yang cukup umur untuk memilih adalah perempuan, dan seiring dengan pertumbuhan umur masyarakat, jumlah pemilih perempuan akan semakin meningkat (Afkhami \& Eisenberg, 2014)(Badan Pusat Statistik Indonesia, 2010). Jumlah perempuan yang lebih banyak daripada laki-laki, berarti jumlah pemilih perempuan akan lebih banyak daripada laki-laki.

Fakta di lapangan menunjukkan hal yang sejalan dengan data yang ada. Jumlah pemilih perempuan di Indonesia pada pelaksanaan Pemilihan Kepala Daerah Tahun 2018 diketahui lebih banyak daripada jumlah pemilih laki-laki (Rahadian, 2018).

Data mengenai partisipasi pemilih perempuan yang lebih tinggi secara signifikan ini menjadi hal yang menarik bagi peneliti untuk ditelusuri lebih jauh. Keterlibatan pemilih perempuan adalah hal yang penting dalam proses demokrasi. Partisipasi perempuan di arena publik dan politik merupakan suatu langkah sangat penting ke arah membangun kembali kondisi ekonomi, politik dan sosial untuk mencapai persamaan bagi perempuan dan laki-laki dalam mendapatkan peluang dan mencapai kemajuan. Partisipasi dari para pemilih dengan memberikan suaranya pada pemilihan umum seringkali dikaitkan dengan tindakan suka rela ataupun memenuhi kewajiban. Penggunaan hak pilih pada Pemilu dianggap sebagai suatu cara warga negara untuk memenuhi tanggungjawabnya (Abdel Rahman Farrag \& Shamma, 2014; Afkhami \& Eisenberg, 2014)

Tingkat partisipasi pemilih (voter turnout) sering menjadi perhatian terutama menjelang pemilu (Ari Ganjar Herdiansah, Junaidi, 2017; Perludem, 2014; Rahmatunnisa, 2017). Voter turnout dianggap sebagai bentuk keberhasil pemilu secara umum. Keterlibatan di bidang politik dipandang positif untuk masyarakat karena membuat demokrasi lebih berarti dan mengakibatkan pemerintahan lebih tanggap dan positif bagi perorangan. Keterlibatan di bidang politik menunjukkan bahwa individu mampu memahami norma sosial dan menjadi warga negara bertanggung jawab. Keputusan memilih ditentukan oleh banyak faktor (Asfar, 1996; Daud, 2015; Muhtadi, 2018). Fenomena partisipasi pemilih perempuan yang lebih besar dibandingkan pemilih laki-laki dapat dijelaskan menggunakan berbagai paradigma. Urgensi peran perempuan dan data bahwa terjadi peningkatan jumlah pemilih perempuan memberikan tantangan untuk mengetahui faktor-faktor apa saja yang sebenarnya menyebabkan voter turnout perempuan lebih tinggi daripada laki-laki (Afkhami \& Eisenberg, 2014; El-Mustafa Benlamlih, 2010; Irmayani, 2017; Sotrisno, 2018). Menurut peneliti, angka tersebut harus ditingkatkan dan dibarengi dengan pemberian edukasi politik berkelanjutan, karena partisipasi politik sesungguhnya tidak hanya memberikan suara. Hal ini seperti yang tercantum dalam laman resmi Koalisi Perempuan Indonesia (KPI) Meskipun terlihat kecenderungan yang menggembirakan, tetapi menurut KPI partisipasi politik perempuan sesungguhnya masih rendah (KPI, 2019). Selain itu persepsi perempuan mengenai politik pun masih negatif, sehingga kondisi saat ini perlu ditelaah agar dapat 
diketahui metode terbaik untuk menjadikannya lebih baik (Nimrah dan Sakaria dkk., 2015; Wahyudi dkk., 2017). Data dan fakta lapangan ini menjadi dasar mengapa penelitian dilakukan. Untuk meningkatkan partisipasi pemilih secara kuantitas dan kualitas dibutuhkan analisis mengenai faktor-faktor apa saja yang mempengaruhinya. Untuk bisa memahaminya, maka dibutuhkan analisis mengenai partisipasi politik, khususnya voter turnout.

Secara garis besar, partisipasi politik terdiri dari partisipasi electoral dan non electoral. Partisipasi elektoral terbagai atas dua kategori yaitu yang sifatnya konvensional, biasanya partisipasi politik dihubungkan dengan tingkat kehadiran pemilih di bilik suara (voter turnout). Sementara yang non-konvensial, sifatnya jauh lebih luas yaitu keterlibatan warga pada proses-proses pemilu seperti kampanye, menjadi relawan, menjadi broker politik calon, dan lain sebagainya. Sedangkan pada kategori partisipasi politik non-elektoral, keterlibatan warga tidak memiliki kaitan atau hubungan dengan pemilu, bentuknya sangat luas, biasanya berkaitan dengan kontroversi politik (contentious politics) seperti gerakan sosial, boikot, protes, menurunkan seseorang dari jabatan politik, protes akibat kebijakan politik, dan lain-lain (Nurhasim, 2014; Surbakti, 1992). Kompleksitas perilaku memilih, yang ditunjukan oleh voter turnout, dipengaruhi oleh berbagai faktor internal dan eksternal. Penelitian oleh Blais, A. dkk., 2011; Blais \& Dobrzynska, 1998; Geys, 2006; Huckfeldt, 1979) menjelaskan kaitan antara status sosial yang tinggi dengan tingkat partisipasi politik : 1) lingkungan sosial memberi dorongan kepada indvidu untuk berpartisipasi, 2) sumber daya dan ketrampilan individu seperti waktu, uang dan pengetahuan, dan 3) karakteristik psikologis, seperti kesadaran dan efikasi politik. Dorongan dari lingkungan sosial adalah faktor yang bersifat eksternal, dimana melalui norma-norma sosial yang ada dapat mendorong individu untuk ikut berpartisipasi sebagai bagian dari sebuah tanggung jawab sosial, sedangkan sumber daya dan karakteristik psikologis lebih bersifat internal.

Partisipasi menjadi salah satu prinsip mendasar dari terlaksana tata pemerintahan yang baik. Partisipasi berasal dari bahasa latin yaitu pars yang artinya bagian dan capere yang artinya mengambil peranan dalam aktivitas atau kegiatan politik negara. Apabila digabungkan berarti "mengambil bagian". Dalam bahasa inggris, partisipate atau participation berarti mengambil bagian atau peranan (Participating | Definition of Participating by Merriam-Webster, 2020). Jadi partisipasi politik berarti mengambil peranan dalam aktivitas atau kegiatan politik negara. Dari segi tipologi para ahli dalam Partisipasi, dapat dibedakan pada dua rumpun yang besar, yaitu pertama, partisipasi politik elektoral, dan kedua partisipasi politik non-elektoral. Partisipasi elektoral terbagai atas dua kategori yaitu yang sifatnya konvensional, biasanya partisipasi politik dihubungkan dengan tingkat kehadiran pemilih di bilik suara (voter turnout). Sementara yang non-konvensial, sifatnya jauh lebih luas yaitu keterlibatan warga pada proses-proses pemilu seperti kampanye, menjadi relawan, menjadi broker politik calon, dan lain sebagainya. Sedangkan pada kategori partisipasi politik nonelektoral, keterlibatan warga tidak memiliki kaitan atau hubungan dengan pemilu, bentuknya sangat luas, biasanya berkaitan dengan kontroversi politik (contentious politics) seperti gerakan sosial, boikot, protes, menurunkan seseorang dari jabatan politik, protes akibat kebijakan politik, dan lain-lain (Huckfeldt, 1979; Leighley, 2010; Nurhasim, 2014). Adapun rincian bentuk partisipasi politik konvensional dan non konvensional adalah : 
1. Partisipasi politik konvensional
a. Pemberian suara atau voting
b. Diskusi politik
c. Kegiatan kampanye
d. Membentuk dan bergabung dalam kelompok kepentingan
e. Komunikasi individual dengan pejabat politik atau administrative

2. Partisipasi politik nonkonvensional
a. Pengajuan petisi
b. Berdemonstrasi
c. Konfrontasi
d. Mogok
e. Tindak kekerasan politik terhadap harta benda : pengrusakan, pemboman, pembakaran
f. Tindakan kekerasan politik terhadap manusia: penculikan, pembunuhan, perang gerilya, revolusi.

Para ahli menyatakan definisi voter turnout dari berbagai dimensi. Paling tidak ada kesamaa ahli menyatakan bahwa voter turnout adalah sejauh mana pemilih yang memenuhi syarat menggunakan suara mereka pada hari pemilihan. Voter turnout diukur sebagai persentase suara yang diberikan pada suatu pemilihan, termasuk suara yang tidak sah. Istilah 'pemilih yang memenuhi syarat' dapat didefinisikan dalam banyak cara (Blais, A. dkk., 2011; Blais \& Dobrzynska, 1998; Geys, 2006; Solijonov, 2016).

Secara umum terdapat dua pendekatan untuk menjelaskan kehadiran pemilih dan ketidakhadiran pemilih dalam suatu pemilu. Pendekatan pertama menekankan pada karakteristik sosial dan psikologi pemilih, serta karakteristik institusional sistem pemilu. Pendekatan kedua menekankan pada harapan pemilih tentang keuntungan dan kerugian atas keputusan mereka untuk hadir atau tidak hadir memilih (Nurhasim, 2014). Huckfeldt, melalui penelitiannya yang dilakukan tahun 1979 mengemukakan bahwa secara umum ada 2 faktor yang mempengaruhi partisipasi pemilih. Konsep yang dikemukan oleh Huckfeltd disempurnakan lagi oleh penelitian Giles dan Dantico tahun 1982. Kemudian konsep yang sama disempurnakan lagi oleh penelitian Hays tahun 2015. Konsep yang diusung oleh Huckfeldt, Giles \& Dantico, serta Hays masuk kedalam kategori pendekatan pertama yaitu menekankan pada karakteristik sosial dan psikologi pemilih (Giles \& Dantico, 1982; Hays, 2015; Huckfeldt, 1979).

Menurut Huckfeldt, Giles \& Dantico dan Hays, partisipasi pemilih tidak bisa dilihat hanya dari konteks individu. Aktivitas politik jarang terjadi dalam isolasi individu; sebagai hasilnya, konteks sosial merupakan penentu penting sejauh mana individu berpartisipasi dalam politik. Karakteristik individu, upeti, dan faktor kepribadian tidak sepenuhnya menentukan tingkat aktivitas politik individu. Orang-orang juga merespons peristiwa, isyarat, dan peluang politik yang spesifik untuk lingkungan tertentu. Faktor sosial eksternal, serta faktor intrinsik individual, memberikan penjelasan kuat untuk partisipasi politik (Giles \& Dantico, 1982; Hays, 2015; Huckfeldt, 1979).

Sejalan dengan penelitian sebelumnya, menurut laporan dari International Institute of Democracy and Electroal Assistance(IDEA) tahun 2016 (Solijonov, 2016) ada banyak penelitian yang telah melakukan penelitian mengenai faktor-faktor yang mempengaruhi voter turnout. Mengenai faktor-faktor tersebut IDEA menguraikannya dalam kategori 
faktor sosial ekonomi, faktor politik, faktor kelembagaan dan faktor individual. Sebagai landasan konsep pengukuran faktor yang mempengaruhi voter turnout, maka peneliti akan menggunakan konsep dari Huckfeldt, Giles \& Dantico dan Hays. Menurut pandangan mereka, faktor yang menentukan voter turnout terdiri dari 2 (dua) kategori faktor individual/internal dan sosial/eksternal. Untuk meningkatkan akurasi hasil ukur, peneliti mengkombinasi faktor-faktor tersebut dengan faktor-faktor yang disampaikan oleh IDEAS.

\section{METODE}

Desain penelitian yang akan digunakan adalah penelitian kuantitatif. Jenis penelitian kuantitatif yang akan digunakan pada penelitian ini berupa kuantitatif inferensial. Penelitian kuantitatif inferensial sendiri merupakan suatu penelitian yang bertujuan untuk menarik kesimpulan berdasarkan analisis yang telah dilakukan. Analisis tersebut dilakukan dengan mengambil sampel tertentu dari suatu populasi yang jumlahnya banyak, dan hasil analisis dari sampel tersebut kemudian dapat digeneralisasikan pada seluruh populasi (Creswell, 2003). Hipotesis yang akan diuji dalam penelitian ini adalah hipotesis asosiatif. Hipotesis asosiatif berarti bahwa penelitian yang dilakukan untuk mengetahui nilai variabel bebas dan terikat (Salim, 2006). Dalam penelitian ini, hipotesis yang akan diuji berkaitan dengan voter turnout pemilih perempuan.

Populasi dapat diartikan sebagai keseluruhan individu atau objek dengan karakteristik-karakteristik tertentu yang ditetapkan oleh peneliti untuk dipelajari (Creswell, 2003). Populasi yang digunakan pada penelitian ini adalah pemilih perempuan di Kota Tanjungbalai. Berdasarkan data KPU Kota Tanjungbalai, jumlah pemilih perempuan yang memberikan hak pilih pada Pemilukada tahun 2018 adalah 33.496 orang. Karakteristik populasi yang akan digunakan adalah pemilih perempuan dan ikut serta dalam Pilkada tahun 2018.

Sampel merupakan bagian populasi yang dipilih untuk diteliti (Creswell, 2003). Sampel minimal harus memiliki satu sifat yang sama dengan populasi agar dapat dilakukan generalisasi. Teknik sampling dapat dibedakan menjadi dua, yaitu (a) dengan menggunakan probabilitas (probability sampling) dan (b) tanpa menggunakan probabilitas (non probability sampling) (Creswell, 2003). Teknik pengambilan sampel yang digunakan penelitian ini adalah teknik pengambilan sampel probabilitas (probability sampling). Pada teknik ini, peneliti memilih sampel berdasarkan kelompok berjenjang (multistage cluster random sampling), mulai dari kecamatan, kelurahan hingga ke kelompok pemilih di TPS.

Instrumen penelitian yang digunakan dalam penelitian ini adalah kuesioner yang dibuat sendiri oleh peneliti, berdasarkan uraian faktor-faktor yang mempengaruhi voter turnout yang disampaikan oleh Huckfeld, Giles dan Dantico, serta Haysdan International Institute of Democracy and Electoral Assistance tahun 2016, yang ditulis oleh Abdurashid Solijonov (Blais \& Dobrzynska, 1998; Geys, 2006; Giles \& Dantico, 1982; Hays, 2015; Huckfeldt, 1979; Solijonov, 2016). Kuesioner akan digunakan untuk menggali variabel-variabel penelitian.

Untuk mencapai akurasi hasil penelitian, maka dilakukan pengujian validitas dan reliabilitas pada instrument penelitian. Proses validasi instrument penelitian dilakukan dengan menggunakan metode validitas isi. Validitas isi dilakukan dengan 2 (dua) 
metode yaitu kualitatif dan kuantitatif (Nisfiannor, 2009). Validitas isi secara kualitatif dilakukan professional judgement. Validitas isi secara kuantitatif dilakukan dengan menggunakan uji korelasi poin biserial. Uji korelasi poin biserial adalah prosedur penghitungan skor pertanyaan dan skor total untuk skor pengukuran yang bersifat dikotomi. Data dalam penelitian ini berbentuk dikotomi, yaitu jawaban Ya diberi skor 1 dan jawaban Tidak diberi skor 0 . Suatu pertanyaan dinyatakan valid jika nilai $r_{\mathrm{pbi}}$ lebih besar daripada $r$ tabel dengan taraf signifikansi atau taraf kekeliruan secara umum 5\% $\left(r_{\text {hit }}>r_{\text {tab }}\right.$ dengan taraf signifikansi $\left.5 \%\right)$. Menurut tabel nilai korelasi poin biserial, untuk pengujian dengan taraf signifikansi $5 \%$ dimana jumlah pertanyaan sebanyak 29 maka nilai $r_{\text {tabel }}$ adalah 0,367 . Berarti pertanyaan dengan nilai $r_{p b i}$ yang lebih besar dari 0,367 , secara statistika dianggap valid. Dari hasil pengujian menggunakan uji korelasi poin biserial, peneliti menyimpulkan bahwa hasil pengukuran terbukti valid. Kesimpulan ini diperoleh dari koefisien korelasi yang bergerak dari koefisien 0,40 hingga 0,99 (lebih besar dari $\left.r_{\text {tabel }}=0,367\right)$. Estimasi reliabilitas di penelitian ini menggunkan metode konsistensi internal. Sesuai dengan karakteristik skor pengukuran di penelitian ini, maka metode estimasi yang dipakai adalah KR-20. Metode ini secara khusus untuk menghitung reliabilitas tes yang datanya dikotomi. Dari hasil estimasi reliabilitas diperoleh koefisien KR-20 yaitu sebesar 0,88 , yang berarti hasil pengukuran dapat dipercaya.

\section{HASIL DAN PEMBAHASAN}

Untuk mengarahkan penelitian, maka peneliti mengajukan hipotesis. Hasil penelitian ini adalah secara statistika ditemukan adanya perbedaan antara faktor internal dan eksternal yang mempengaruhi voter turnout kalangan pemilih perempuan di Kota Tanjungbalai. Hasil ini hanya menunjukkan bahwa ada besaran peluang yang berbeda yang dipengaruhi oleh faktor internal dan eksternal. Dari hasil penelitian terlihat bahwa faktor eksternal adalah proporsinya paling besar. Maknanya adalah responden lebih banyak mengaku bahwa faktor eskternal yang menjadi alasannya untuk memberikan suara. Meskipun begitu penelitian ini tidak fokus pada faktor apa yang paling mempengaruhi. Hasil ini menunjukkan bahwa peluang seorang perempuan memberikan suaranya dipengaruhi oleh banyak faktor, bukan hanya dari dalam dirinya sendiri tetapi juga berasal dari luar dirinya. Hasil ini mendukung banyak penelitian terdahulu (Daud, 2015; Irmayani, 2017; Muhtadi, 2018) yang menyatakan bahwa faktorfaktor yang menyebabkan seseorang memberikan suaranya adalah sebuah fenomena yang kompleks.

Jika ditinjau secara internal, maka ada 7 (tujuh) faktor internal yang diteliti dalam penelitian ini, dalam konteks pengaruh terhadap voter turnout kalangan perempuan di Kota Tanjungbalai. Faktor internal pertama adalah pandangan pemilih mengenai kandidat/partai. Hasil penelitian menunjukkan bahwa faktor ini tidak menjadi faktor yang mempengaruhi voter turnout kalangan perempuan di Kota Tanjungbalai. Secara deskriptif, terlihat bahwa proporsi responden yang menjadikan faktor ini sebagai alasan dan bukan alasan tidak terlalu besar jaraknya.

Faktor internal selanjutnya adalah pandangan pemilih mengenai kampanye. Menurut hasil penelitian, ditemukan bahwa faktor ini tidak mempengaruhi voter turnout di kalangan perempuan Tanjungbalai. Secara deskriptif juga ditemukan hasil yang setara, bahwa lebih banyak responden yang tidak menjadi kampanye sebagai alasan 
yang mendasari keputusan pemberian suaranya. Penelitian sebelumnya menyatakan bahwa kampanye yang dilakukan besar-besaran mungkin memiliki efek positif pada tingkat partisipasi. Argumen yang disampaikan adalah karena kampanye dapat meningkatkan tingkat informasi dan kesadaran pemilih untuk berpartisipasi dalam pemilu (Dawson dan Zinser, 1976; Chapman dan Palda, 1983). Meskipun begitu dijelaskan lagi bahwa setiap usah kandidat dalam kampanye memang belum tentu membawa pemilih memberikan suaranya. Dalam kondisi ini, kalangan perempuan di Kota Tanjungbalai juga menyatakan bahwa kampanye bukanlah alasan yang mendasari kegiatan pemberian suara. Kemungkinan hasil ini dapat dijelaskan seperti yang disampaikan oleh Ansolabehere dkk. (1994). Jika kampanye yang terjadi adalah kampanye negative, maka pemilih akan cenderung menurunkan dukungannya, yang pada akhirnya mempengaruhi voter turnout. Kampanye negatif juga menciptakan pandangan negative pemilih tentang politik secara umum. Tapi argumen juga harus diinvetigasi lagi dalam bentuk penelitian lanjutan.

Faktor internal selanjutnya adalah usia. Berdasarkan hasil penelitian, faktor usia signifikan mempengaruhi voter turnout pada kalangan perempuan di Kota Tanjungbalai. Secara deskriptif, mayoritas responden juga menyatakan bahwa usia adalah hal yang menjadi alasan mengapa mereka memberikan suara. Jika dikontekskan dengan pertanyaan kuesioner, responden kemungkinan beranggapan bahwa semakin matang usia, pemilih merasa semakin penting untuk mengikuti pemilu. Kondisi ini seperti yang disampaikan oleh Wolfinger \& Rosenstone, 1980 (dalam Blais \& Dobrzynska, 1998)yang menyatakan bahwa semakin rendah usia pemilih, semakin rendah jumlah pemilih. Meskipun begitu menurut mereka perlu diteliti lebih lanjut karena kemungkinan usia yang lebih muda adalah kelompok yang jarang terekspos pada politik sehingga enggan memilih.

Faktor selanjuntnya adalah tingkat pendidikan. Menurut hasil penelitian, diketahui bahwa tingkat pendidikan Hipotesis nomor 5 tidak terbukti, berarti bahwa di kalangan perempuan Tanjungbalai tingkat pendidikan tidak mempengaruhi voter turnout. Contoh kasus di Jakarta, bahwa pemilih yang memiliki pendidikan yang lebih tinggi tidak lebih besar dari pada kelompok pemilih yang memiliki pendidikan yang lebih rendah.

Faktor selajutnya adalah minat politik. Menurut hasil penelitian, faktor ini terbukti mempengaruhi voter turnout kalangan perempuan di Kota Tanjungbalai. Secara deskriptif terlihat bahwa mayoritas responden tidak menjadikan faktor ini sebagai alasan yang mendasari pemberian suara. Maka itu kemungkinannya pengaruh yang diberikan oleh faktor ini adalah pengaruh negatif, meskipun hasil ini harus dibuktikan melalui penelitian lebih lanjut. Kemungkinan hal ini berkaitan dengan tanggung jawab moral pemilih sebagai bagian dari organisasi politik yang sudah seharusnya mensukseskan pemilihan.

Faktor selanjutnya adalah hal sebagai warga negara. Faktor ini ditemukan signifikan berpengaruh terhadap voter turnout kalangan perempuan di Kota Tanjungbalai. Secara deskriptif, mayoritas responden menjadikan faktor ini sebagai alasan yang mendasarinya memberikan suara. Hal ini dapat terjadi karema kemungkinan pemilu adalah kegiatan periodical, dimana kegiatan ini diyakini sebagai cara untuk membuktikan tanggung jawabnya sebagai warga negara. Secara teoritis ternyata faktor ini juga berhubungan dengan pelaksanaan kampanye. Dengan pelaksanaan kampanye menurut Cox dan Munger, 1989, dapat memberikan informasi 
tentang para kandidat dan secara bersamaan meningkatkan kesadaran pemilih mengenai haknya sebagai warga negara.

Secara eksternal ada 9 (sembilan) faktor yang menjadi objek penelitian. Faktor eksternal tersebut meliputi : ukuran populasi ; stabilitas populasi ; kondisi pembangunan ekonomi ; jarak perolehan suara ; fragmentasi politik ; sistem pemilihan ; waktu pelaksanaan pemilu ; persyaratan pendaftaran dan pengaturan pemberian suara.

Faktor eksternal pertama yang akan dibahas adalah ukuran populasi. Menurut hasil penelitian, faktor ini secara statistika signifikan mempengaruhi proporsi voter turnout kalangan perempuan di Kota Tanjungbalai. Populasi yang kecil di Kota Tanjungbalai membuat pemilih merasa bahwa suaranya akan memberikan dampak yang signifikan. Secara teoritis, para ahli menyampaikan bahwa ada hubungan antara ukuran komunitas dan jumlah pemilih (Dahl \& Tufte, 1973 ; Verba, Nie \& Kim, 1978; Blais \& Dobrzynska, 1998). Penelitian menunjukkan jika karakteristik sosial-ekonomi individu dikontrol, kegiatan komunal seperti memberi suara di pemilu terlihat lebih lazim di lingkungan yang lebih kecil. Data menunjukkan bahwa kehidupan sosial dan politik cenderung lebih tidak terjadi di komunitas yang lebih besar. (Verba \& Nie 1972). Blais dan Carty (1990) bahwa jumlah pemilih cenderung lebih tinggi di negara-negara yang lebih kecil. Jika dianalogikan dengan jumlah penduduk, kota Tanjungbalai adala tergolong kota sedang. Kategorisasi ini adalah berdasarkan Peraturan Pemerintah (PP) Nomor 26 Tahun 2008, kota di Indonesia diklasifikasikan menjadi 4 kategori berdasarkan jumlah penduduk, yaitu: kota kecil (sampai dengan 100.000 jiwa), kota sedang (lebih dari 100.000 sampai dengan 500.000 jiwa), kota besar (lebih dari 500.000 sampai dengan 1.000.000), dan kota metropolitan (lebih dari 1.000.000 jiwa). Kota Tanjungbalai memiliki jumlah penduduk sekiatar 150.000 (Data BPD tahun 2010). Meskipun tidak ada perbandingan dari kota-kota tetangganya, tapi hasil ini dapat dijadikan prediksi untuk penelitian lain yang membutuhkan kajian mengenai ukuran populasi. Jika ditinjau dari laporan deskriptif, diketahui bahwa proporsi yang menyatakan bahwa faktor ini adalah alasan untuk memberikan suara lebih besar daripada proporsi kebalikannya. Hasil ini berarti mendukung prediksi yang disampaikan oleh ahli-ahli sebelumnya. Hipotesis nomor 9 terbukti, berarti bahwa pandangan tentang stabilitas populasi dikalangan perempuan Tanjungbalai mempengaruhi voter turnout. Faktor ini berkaitan dengan semakin lama seseorang berada di suatu daerah, maka akan semakin mudah baginya untuk mengikuti semua tahapan pemilu. Sehingga semakin lama seseorang berada di daerah itu akan membuat dirimu semakin merasa memiliki daerah tersebut (dalam artian harus berkontribusi kepada daerah tersebut).

Faktor eskternal selanjutnya adalah stabilitas populasi. Hasil penelitian menunjukkan bahwa faktor ini secara signifikan berpengaruh pada voter turnout kalangan perempuan di Kota Tanjungbalai. Dari perspektif teoretis, stabilitas populasi dapat diharapkan untuk meningkatkan tingkat partisipasi karena tiga alasan. Pertama, populasi yang stabil meningkatkan perasaan identifikasi dan kepatuhan kelompok (Hoffman-Martinot, 1994; Ashworth dkk., 2002) dan dengan demikian muncul tekanan sosial untuk melakukan pemberian suara. Kedua, tinggal di area yang sama untuk periode waktu yang lebih lama cenderung meningkatkan pengetahuan tentang isu-isu dan kandidat lokal. Ini pada gilirannya meningkatkan pengetahuan mengenai tata cara atau prosedur pemungutan suara (Filer et al., 1993). Akhirnya, migrasi yang lebih tinggi (keluar dari satu daerah) dapat mengindikasikan non-voting yang lebih tinggi karena 
pemilih potensial dapat tinggal di tempat lain dalam waktu dekat dan tidak terpengaruh oleh kebijakan lokal.

Faktor eksternal selanjutnya adalah kondisi pembangunan ekonomi setempat. Hasil penelitian menunjukkan bahwa kondisi pembangunan ekonomi setempat dikalangan perempuan Tanjungbalai mempengaruhi voter turnout. Kemungkinan pemilih merasa bahwa jika ia ikut memilih maka hal itu akan berpengaruh pada peningkatan aktivitas perekonomian setempat. Secara deskriptif, diketahui bahwa proporsi responden yang menjawab Ya untuk alasan kondisi pembangunan ekonomi memang lebih besar daripada yang menyatakan faktor ini bukan alasan pemberian suara. Kondisi ini sesuai dengan hasil penelitan Powel ; Crewe ; Jackman (dalam (Blais \& Dobrzynska, 1998). Menurut para ahli kondisi ekonomi merupakan hipotesis paling penting untuk diuji dalam kaitannya unutk mendorong partisipasi. Alasan yang mendasari hipotesis ini adalah bahwa pembangunan ekonomi membuat orang lebih terinformasi dan terlibat dalam proses politik (Powell 1982: 37). Powell memang menemukan korelasi positif antara pembangunan ekonomi dan jumlah pemilih tetapi Crewe (1981) dan Jackman (1987) melaporkan tidak ada korelasi seperti itu. Perbedaan ini dapat berasal dari fakta bahwa para peneliti ini memeriksa sampel yang berbeda. Ada juga kemungkinan bahwa hubungan tersebut tidak linier, bahwa apa yang diperlukan untuk partisipasi yang baik adalah tingkat perkembangan ekonomi yang sederhana tetapi bahwa pada ambang batas tertentu lebih banyak pembangunan tidak memiliki dampak tambahan pada jumlah pemilih.

Faktor eksternal selanjutnya adalah jarak perolehan suara antar kandidat/partai. Hasil penelitian menunjukkan bahwa faktor ini secara statistika tidak signifikan berpengaruh terhadap voter turnout kalangan perempuan di Kota Tanjungbalai.Kemungkinan hal ini dapat dijelaskan karena pemilih tidak mengetahui bahwa akan terjadi jarak antara perolehan suara, sehingga pemilih tidak terpengaruh dengan hal tersebut. Hasil ini sesuai penjelasaan yang diberikan oleh Blais \& Dobrzynska, (1998) bahwa jarak perolehan suara tidak memiliki efek langsung terhadap voter turnout. Hasil secara deskriptif juga mendukung hasil penelitian. Hasil secara deskriptif menunjukkan bahwa proporsi yang lebih besar adalah responden menyatakan bahwa jarak perolehan suara bukanlah yang menjadi alasan yang mendorongnya memberikan suara.

Faktor eksternal berikut adalah fragmentasi politik. Fragementasi politk adalah seberapa banyak jumlah partai atau kandidat yang bertarung di pemilu. Berdasarkan hasil penelitian, diperoleh bahwa di kalangan perempuan Tanjungbalai fragmentasi politik mempengaruhi voter turnout. Sesuai dengan tujuan penelitian maka makna pengaruh disini belum mengacu pada kesimpulan satu arah, sehingga tidak diketahui apakah pengaruh yang terjadi adalah positif atau negatif. Penelitian ini hanya fokus pada perbedaan proporsinya yaitu yang menjawab Ya untuk alasan fragmentasi politk dan Tidak untuk alasan fragmentasi politik. Dilihat dari kontek proporsi, yang lebih besar adalah proporsi responden yang menjawab Tidak, yang berarti lebih banyak yang menyatakan bahwa dia memberikan suara bukan karena fragmentasi politik.Secara teori diketahui bahwa semakin besar jumlah partai, semakin banyak pilihan yang ditawarkan, dan semakin tinggi jumlah pemilih (Blais, A. dkk., 2011; Blais \& Dobrzynska, 1998). Meskipun begitu, ada banyak diskusi yang terjadi berkaitan dengan fragmentasi politik, karena ada penelitian lain juga yang menyimpulkan bahwa semakin besar jumlah 
partai, maka semakin kecil pula angka turn out (Jackman, 1986 ; Blais \& Dobrzynska, 1998). Hasil penelitian kemungkinan terjadi karena Pemilihan Gubernur \& Wakil Gubernur Provinsi Sumatera Utara, jumlah kandidat hanya ada 2 (dua) pasang sehingga fragmentasi politknya kecil. Jika benar hal ini terjadi, maka kondisi di Kota Tanjungbalai sesuai dengan prediksi dari Jackman (1986), bahwa semakin besar jumlah partai, maka semakin kecil pula angka turn out.

Faktor eksternal selanjutnya adalah sistem pemilihan. Menurut hasil penelitian, sistem pemilihan mempengaruhi voter turnout kalangan perempuan di Kota Tanjungbalai. Jika dilihat secara deskriptif, mayoritas responden menyatakan bahwa sistem pemilihan adalah alasan yang mendasari mereka memberikan suara. Hal ini terlihat dari proporsi jawaban Ya yang lebih tinggi daripada jawaban tidak. Secara teoritis, sistem pemilihan memang mempengaruhi voter turn out. Sistem pemilihan langsung seperti yang dilaksanakan di pilkada di Indonesia menurut pada ahli berkaitan dengan peningkatan voter turnout. Menurut Ladner \& Miller, 1991, sistem pemilihan langsung mungkin lebih mudah dipahami oleh pemilih rata-rata. Ini merangsang partisipasi dalam sistem seperti itu dibandingkan dengan sistem proporsional yang 'lebih sulit'. Kedua, sistem proposional sering melibatkan format koalisi, sehingga membingungkand dan membuat pemilih menjadi lebih tidak puas terhadap hasil pemilu. Lebih lanjut sistem pemilihan di pilkada, yang merupakan pemilihan langsung yang kemungkinan membuat pemilih merasa lebih dekat dengan kandidat yang dipilihnya, sehingga pemilih lebih mau memberikan suara.

Faktor selanjutnya adalah waktu pelaksanaan pemilu. Menurut hasil penelitian, faktor ini terbukti mempengaruhi voter turnout kalangan perempuan di Kota Tanjungbalai. Secara deskriptif mayoritas responden menyatakan bahwa waktu pemilihan umum adalah alasan yang mendasarinya untuk memberikan suara, terlihat dari proporsi jawaban Ya yang lebih besar daripada jawaban Tidak. Secara teoritis, dalam artikelnya Geys (2006) menuliskan bahwa ada hubungan antara waktu pelaksanaan yang dilaksanaan bersamaan dengan peningkatan voter turn out. Menurut Geys (2006) di beberapa negara, beberapa pemilihan diselenggarakan secara bersamaan. Pemilu serentak ini dapat diperkirakan akan memengaruhi peningkatan jumlah pemilih karena setiap pemilih secara individu kemungkinan besar menjadi merasa mempedulikan pemilu, karena semua orang juga akan memberikan suara. Secara teoritasi paling tidak ada dua alasan mengapa hubungan ini dapat terjadi. Pertama, lebih banyak orang yang terlibat meningkatkan kemungkinan bahwa media memperhatikan proses ini dan hal ini meningkatkan kesadaran umum mengenai pemilu (Cox dan Munger, 1989). Pada kondisi riilnya, pemilu tahun 2018 dilaksanakan pada hari libur atau hari yang diliburkan dengan demikian hal ini membantu pemilih untuk memberikan suaranya. KPU Tanjungbalai sebelum hari pemilihan melakukan sosialisasi ke perusahaan-perusahaan swasta secara persuasive untuk memberikan hari libur kepada karyawan agar bisa memberikan suara. Untuk pemilih yang berasal dari luar kota, yang tidak memungkinkan untuk kembali ke Kota Tanjungbalai, KPU mengeluarkan form A5.

Faktor selanjutnya adalah persyaratan pendaftaran. Menurut hasil penelitian, faktor ini mempengaruhi voter turnout kalangan perempuan di Kota Tanjungbalai. Secara deskriptif, responden mayoritas mengakui bahwa faktor ini menjadi alasan yang mendasarinya memberikan suara. Secara teoritis para ahli menyatakan bahwa 
persyaratan pendaftaran yang lebih mudah akan meiningkatkan voter turnout. Menurut Kelley dkk, 1967 dan Rosenstone dan Wolfinger 1978, persyaratan pendaftaran yang mudah akan meningkatkan kompensasi psikologis untuk melakukan pemberian suara. Yang dimaksud dengan kompensassi disini adalah karean persyaratannya sangat mudah maka energi yang dihabiskan juga sangat kecil shingga besar kemungkinan pemilih akan ikut serta. Jika dilihat dari kondisi di lapangan, persyaratan pendaftaran saat pilkada 2018, adalah pilkada ke 3 yang sudah berulang, sehingga pemilih sudah paham cara melakukan pendaftaran. KPU sudah melakukan coklit sejak dari awal pendaftaran, hingga hari akhir. Bagi yang tidak terdaftar di DPT, maka pemilih bisa langsung dating ke TPS untuk memberikan suara setelah pukul 12:00 WIB.

Faktor terakhir adalah pengaturan pemberian suara. Faktor ini ditemukan berpengaruh pada voter turnout. Menurut hasil penelitian, faktor ini ditemukan berpengaruh terhadap voter turnout kalangan perempuan di Kota Tanjungbalai. Secara deskriptif, mayoritas pemilih setuju bhawa pengaturan pembeiran suara adalah asana yang mendasarinya unutk melakukan pemberian suara. Faktor ini sebenarnya dapat dijelaskan dengan konsep teoritis mengenai pengaruh sistem politik yang telah disampaikan sebelumnya. Sistem pilkada memiliki pengaturan pemberian suara yang tidak kompleks sehingga pemilih merasa lebih ingin terlibat.

\section{SIMPULAN DAN SARAN}

Berdasarkan pengujian hipotesis disimpulkan hal-hal berikut ini yaitu ditemukan perbedaan pengaruh dari faktor internal dan eksternal terhadap voter turn out pada kalangan perempuan di Tanjungbalai. Faktor internal yang berpengaruh pada voter turn out di kalangan perempuan Tanjungbalai adalah : usia, minat terhadap politik dan pandangan pemilih mengenai hak warga negara. Faktor eksternal yang berpengaruh pada turn out di kalangan perempuan Tanjungbalai adalah : ukuran populasi, stabilitas populasi, kondisi pembangunan ekonomi setempat, fragmentasi politik, sistem pemilihan, waktu pelaksanaan pemilu, persyaratan pendaftaran sebagai pemilih dan pengaturan pemberian suara.

Diperlukan penelitian lebih lanjut dengan kriteria pengujian satu pihak, untuk mengetahui faktor mana yang lebih berpengaruh terhadap voter turnout.Diperlukan penelitian lebih lanjut untuk mengetahui arah pengaruh dari setiap faktor, apakah pengaruh yang disebabkan adalah positif atau negative.Penelitian dengan tema seperti ini perlu dilakukan dengan mengunakan metode campuran kuantitatif dan kualitatif. Metode kuantitatif berusaha mencari sebab akibatnya, sedangkan metode kualitatif berusaha menjelaskan mengapa faktor-faktor tertentu dapat mempengaruhi voter turn out.Bagi pembaca yang merupakan bagian dari penyelenggara pemilu di Kota Tanjungbalai, perlu dipikirkan sosialisasi yang menyasar faktor-faktor internal kalangan perempuan agar peluang mereka memberikan suara saat pemilu menjadi lebih tinggi. Bagi pembaca yang merupakan bagian dari peserta pemilu di Kota Tanjungbalai, perhatikan bahwa faktor-faktor eksternal lebih banyak yang mempengaruhi voter turnout kalangan perempuan. 


\section{DAFTAR PUSTAKA}

Abdel Rahman Farrag, D., \& Shamma, H. (2014). Factors influencing voting intentions for Egyptian parliament elections 2011. Journal of Islamic Marketing, 5(1), 49-70. https://doi.org/10.1108/JIMA-01-2013-0003

Afkhami, M., \& Eisenberg, A. (2014). Buku Panduan Partisipasi Politik untuk Perempuan (hIm. 1-73). International Foundation for Electoral Systems. https://www.ifes.org/sites/default/files/gender_equality_and_emb_best_practices_ guide_final_bahasa.pdf.pdf

Ari Ganjar Herdiansah, Junaidi, H. I. (2017). Pembelahan Ideologi, Kontestasi Pemilu, Dan Persepsi Ancaman Keamanan Nasional: Spektrum Politik Indonesia Pasca 2014? Jurnal Wacana Politik, 2(1), 61-73.

Asfar, M. (1996). Beberapa Pendekatan dalam Memahami Perilaku Pemilih,. Jurnal IImu Politik.

Badan Pusat Statistik Indonesia. (2010). Sensus Penduduk 2010-Indonesia. https://sp2010.bps.go.id/ http://sp2010.bps.go.id/

Blais, A., Anduiza, E., \& Gallego, A. (2011). Decentralization and Voter Turnout. https://journals.sagepub.com/doi/abs/10.1068/c1015r

Blais, A., \& Dobrzynska, A. (1998). Turnout in Electoral Democracies. European Journal of Political Research, 33(2), 239-261. https://doi.org/10.1111/1475-6765.00382

Budiardjo, M. (2004). Dasar-dasar ilmu politik. Gramedia. https://books.google.co.id/books?id=_dZ247rCydlC\&lpg=PR11\&ots=$z E E M 1 X X D h \& d q=i l m u$ politik\&Ir\&pg=PP1\#v=onepage\& $q=i l m u$ politik\& $f=$ false

Creswell, J. W. (2003). Research design, Qualitative, Quantitative, Mixed Methods Approaches. Sage Publications.

Daud, M. (2015). PREDIKTOR PERILAKU PEMILIH PADA PEMILUKADA: Perspektif

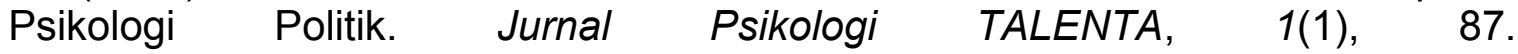
https://doi.org/10.26858/talenta.v1i1.5235

El-Mustafa Benlamlih. (2010). Partisipasi Perempuan dalam Politik dan Pemerintah.

Geys, B. (2006). Explaining Voter Turnout: A Review of Aggregate-Level Research. Electoral Studies, 25, 637-663. https://doi.org/10.1016/j.electstud.2005.09.002

Giles, M. W., \& Dantico, M. K. (1982). Political Participation and Neighborhood Social Context Revisited. American Journal of Political Science, 26(1), 144-150. JSTOR. https://doi.org/10.2307/2110844

Hays, R. A. (2015). Neighborhood Networks, Social Capital, and Political Participation: The Relationships Revisited. Journal of Urban Affairs, 37(2), 122-143. https://doi.org/10.1111/juaf.12137

Huckfeldt, R. R. (1979). Political Participation and the Neighborhood Social Context. $\begin{array}{llll}\text { American Journal of Political Science, } & 579 .\end{array}$ https://doi.org/10.2307/2111030

Irmayani, T. (2017). Perilaku Perempuan Pemilih dalam Menetapkan Pilihan Pada Pemilu 2009. Politeia: Jurnal IImu Politik.

KPI. (2019). Ayo pantau pemilu! https://www.koalisiperempuan.or.id/2019/04/16/ayopantau-pemilu/

Leighley, J. E. (Ed.). (2010). The Oxford Handbook of American Elections and Political Behavior. Oxford University

Press. https://doi.org/10.1093/oxfordhb/9780199235476.001.0001 
Muhtadi, B. (2018). Politik Identitas dan Mitos Pemilih Rasional. MAARIF Journal, 13(2), 68-86.

Nimrah dan Sakaria, S., Kunci, K., \& Patriarki, dan B. (2015). Perempuan Dan Budaya Patriarki Dalam Politik (Studi Kasus Kegagalan Caleg Perempuan Dalam Pemilu Legislative 2014 ). The POLITICS: Jurnal Magister IImu Politik Universitas Hasanuddin.

Nisfiannor, M. (2009). Pendekatan statististika Modern untuk IImu Sosial. Penerbit Salemba.

Nurhasim, Moh. (Ed.). (2014). Partisipasi pemilih pada pemilu 2014: Studi penjajakan. PUSAT PENELITIAN POLITIK LEMBAGA ILMU PENGETAHUAN INDONESIA DAN KOMISi PEMILIHAN UMUM.

Participating | Definition of Participating by Merriam-Webster. (2020). https://www.merriam-webster.com/dictionary/participating

Perludem. (2014). Mendorong Partisipasi Masyarakat dalam Pemilu 2014. http://perludem.org/2014/02/20/mendorong-partisipasi-masyarakat-dalam-pemilu2014/

Rahadian, L. (2018). KPU: Jumlah Pemilih di Pilkada 2018 Ada 152 Juta Orang. tirto.id. https://tirto.id/kpu-jumlah-pemilih-di-pilkada-2018-ada-152-juta-orang-cGuf

Rahmatunnisa, M. (2017). Mengapa Integritas Pemilu Penting? Jurnal Bawaslu.

Salim, A. (2006). Teori \& paradigma penelitian sosial (2 ed.). Tiara Wacana.

Solijonov, A. (2016). Voter Turnout Trends around the world | International IDEA. International Institute for Democracy and Electoral Assistance. https://www.idea.int/publications/catalogue/voter-turnout-trends-around-world

Sotrisno, S. (2018, April 22). KPU: Daftar Pemilih Tetap Pilkada Sumut, Lebih Dominan Perempuan [News]. kicaunews.com. https://kicaunews.com/2018/04/22/kpudaftar-pemilih-tetap-pilkada-sumut-lebih-dominan-perempuan/

Surbakti, R. (1992). Memahami llmu Politik. Grasindo.

Wahyudi, J., Milla, M. N., \& Muluk, H. (2017). Persepsi Keadilan Sosial dan Kepercayaan Interpersonal sebagai Prediktor Kepercayaan Politik pada Mahasiswa di Indonesia. Jurnal Psikologi Sosial. https://doi.org/10.7454/jps.2017.6 